\title{
Linguoculturological Analysis of the Concept of «Health»
}

\author{
Liudmila Kiseleva \\ Candidate of Sciences in Economics, Associate Professor, Institute of Management and Business \\ Tyumen State Oil and Gas University, Volodarskogo St., 38, Tyumen, Russian Federation; Email: kiseleva-l@mail.ru
}

\author{
Doi:10.5901/mjss.2016.v7n3s1p291
}

\begin{abstract}
The concept of «health» comprises complex structured mental formations that include notional, figurative, and value features, partially coinciding and differing in various linguocultures. The paper contains an analysis of origin of the word "health» in linguistic branches of Indo-European stem. It is found that the origin and meaning of the word «здоровье» (health), fixed in the Russian language, is older, than the meaning of health as an «integrity of all systems of the organism», fixed in the Roman and Germanic linguistic branches. Health is a lasting value of universal type, but the content and actualization of peculiar features of the concept is different. During comparison between figurative meanings of the concept of "health» a similarity between the Russian and English languages is discovered (health is the most important value, influence of Christian traditions), though there are some differences. There are more differences in comparison with the Chinese language. The found ethnocultural specific features are caused by different development levels of each of the analyzed culture and different view of the world.
\end{abstract}

Keywords: integrity, wellness, longevity, gift, good.

\section{Introduction}

At present in the scientific literature there are more than a hundred definitions of the notion of health, which reflect approaches of different sciences. Being a universal value, health carries a decisive meaning for the whole human life. Health in all variants of the society, forms of denomination, various nationalities is within the highest, unquestionable, historically determined values, which is caused by a certain organization of a human, in particular, by a sense of selfprotection, typical for all flesh (Kozyr, 2007). Nevertheless, the value of health at various times among various nations was different.

Conceptions of health changed together with a change of civilizations, cultures, epochs, production methods, etc. In the primitive society physical health was very important, because it was physical health that determined whether this or that individual would survive. As more complicated production and more complex organization of social interactions appeared, a value formation process changed. The values acquired general and abstract nature. The language reflects all the specific features of these conceptions, like a mirror. As a means of human communication and, therefore, social and national in its nature, the language cannot but carry the imprints of specific features of the world view, ethic and cultural values, as well as norms of behavior, typical for the given linguistic community (Derbisheva, 2003).

The concept of «health» belongs to the most important human vital guideline, so it acquires numerous lexical and phraseological designations in the language. The aim of the paper is to perform a linguoculturological analysis of the concept of «health» in various national cultures. We suppose that an account for interaction between the language and culture would enable us to distinguish notional, figurative, and value features of the concept of «health», partially coinciding and differing in various linguocultures.

The paper has the following structure. In the first part of the paper we define the research hypothesis and methods, with the help of which the analysis of units in various languages is performed. In the second part there is a comparative analysis of component structures of the lexemes of health, the cultural meanings of the notion of «health» are discussed.

\section{Hypothesis}

We base on an assumption that the concept of «health» has national and cultural specific features, caused by differences in the hierarchy of values. The contemporary cognitive research shows that in each culture there are its own «standards of health», which reflect meaningful conceptions about health and illness in the certain nation's linguistic world image during the cultural-historical development process and their formation, differentiation, and variation. In this respect, they may be considered as specific mental constructs, or concepts, reflecting ethnopsychological peculiarity, typical for the 
given nation's world image.

In our viewpoint, it is the linguoculturological analysis and its methodology that enable to study the national world image, linguistic consciousness and peculiarities of mental and lingual complex in interrelation.

\section{Methods}

For carrying out research over a complex target - language and culture interaction - we have used the following methods in a certain combination: comparative historical, etymological analysis, lexicographical analysis, contextual analysis, analysis of proverbs. The research of origin of the word «health» is based on a comparison of several branches of the Indo-European stem.

The lexicographical analysis has enabled to distinguish similar and different lexicographical semantic invariants in various languages. The concepts of «health» in the Russian, English, and Chinese languages were analyzed as examples.

The proverb analysis has enabled to estimate the degree of expression of a universal and specific cultural component of the concept of «health», reflecting the state of national language consciousness during several hundred years.

The contextual analysis gives an opportunity to distinguish ideas about the concept of «health», which were formed by various people under the influence of a number of psychological, social-economic, nature-climatic, phenomena, acting during the long-term evolution of a certain country.

The etymological analysis contributes to determination of the origin of the word «health» in the group of IndoEuropean languages and distinguishing the unity of the root, or, visa-versa, the existing differentiation in etymology. The comparative historical analysis is a basis of for assessment of fixing and evolution of the concept of «health» in the cultural and social structures of various societies in the historical retrospective.

\section{Linguocultural Specific Features of the Concept of «Health» in Vareous Language Views}

As a starting point for our research we would take the definition of concept, given by V.A. Maslova (2004, p. 36), in accordance to which «concept is a semantic formation, marked by linguocultural specific features and characterizing bearers of a certain enthnoculture, which is surrounded by an emotional, expressive, evaluating halo». Let us address the target of our research - the concept of «health», which is verbalized in the Russian language with the word здоровье [zdorovye], being the name of the concept.

Perhaps, there is no other language, where the idea of health is developed in such a high value, as Russian. The research of a prominent Russian linguist and philologist V.V. Kolesov, dealing with history of Old Russian words, show that the word «здоровье» had no meaning known to us in the Ancient Rus. «At the ancient times the word «здоровье» did not yet have the meaning usual to us, it was pronounced differently - съдоров and meant «strong as a tree»; its usage in address to a human was no more than a metaphor» (Kolesov, 1986, p. 61). The Common Slavic *sъdorvъ, where sъ corresponded to the Old Indian su - «good» and *dorvo -from a tree (compared to the Old Indian «dāru» «log»), which literally meant - from a good tree (Etymological Dictionary by M. Vasmer). Known from the ancient Russian times greetings «Здорово!» [zdorovo] (hi!), «Здравствуй!» [zdravstvuy] (how do you do!) were formed from a wish to be hard and strong as a forest tree».

In all Slavic languages of the Indo-European stem (Fig. 1) the word «здоровье» is pronounced in a similar manner: the Czech - zdravý, Polish - zdrowy, Bulgarian - здрав, Slovenian -zdráv, etc. G. Gachev (2007) writes about peculiarities of perception of a tree (forest) in various cultures. A specific nature of Russian perception of a tree bases upon the idea that it gives human an ideal example of individuality, which should be strong and whole. 


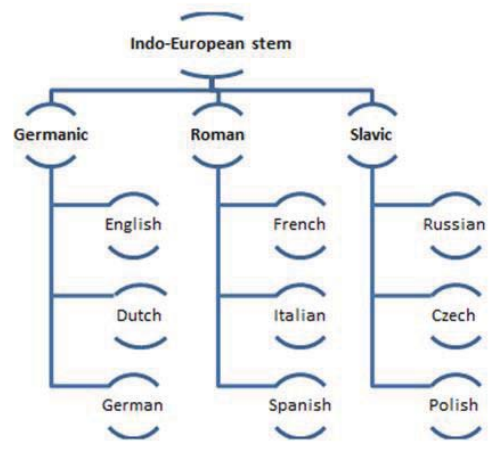

Figure 1.Genealogical tree of Indo-European languages (incomplete scheme) [The World Atlas of Languages, 1998, p. 25]

In the Germanic language branch the origin of the word «health» has another direction. The English word healthhas the Old-English root hal - whole, undamped, which took its origin from the Old-German heil - great, whole. Before it goes the Indo-European structure *kai-Io-, *kai-Iu-, comprising co-existing features «whole», «healthy», «unharmed». The examples from the Modern English are to heal and healing. The sense is the following: «whole» means «healthy». The whole individuality, the whole body, the whole soul $=$ a healed person.

The word «health» in the Modern Roman languages: in French - «santé»; in Italian - «salute»; in Spanish «salud». The origin of the given words goes from the Medieval Latin salus from the Old Indian *soluos/*soruos - «whole» (Etymological Dictionary by M. Vasmer). O.V. Milic (2014), investigating the concept of health in the culture of ancient Romans, pointed out that the verbal representative salus has a wide semantic range: from designating psycho-somatic health to prosperity in the individual and social aspects. Salus in the meaning «good» is represented by the semes «rescue», «life saving». In the French language we have met the word «robuste» in the meaning «healthy» (Makarov, 1916): Quelle femme robuste! What a healthy woman!. Though, in the contemporary dictionaries such adjective with regard to health description is no longer used. It was formed from the Latin rōbustus «oak, strong, healthy» - from rōbur «oak wood, oak tree». We state that in the modern Roman-Germanic languages the sense content, related to the notion of wholeness, is preserved. It is obvious that it is the Russian language, where the word «health» in its older meaning «strong as a tree» is fixed.

The concept of health is an abstract one. It is not a concrete object, which one is able to see, hear, or touch. But people perceive its importance through figurative concepts, consider health as a valuable thing - wealth, treasure, gold. Table 1 presents notional, figurative, and value features of the concept of «health» in the Russian, English and Chinese linguocultures.

Table 1.Analysis of features of the concept of «health» in various linguocultures.

\begin{tabular}{|c|c|c|c|}
\hline Feature & Russian language & English language & Chinese language \\
\hline Health as a value & $\begin{array}{l}\text { Health in the Russian national } \\
\text { consciousness is the most } \\
\text { important value, which is put } \\
\text { higher than material goods. } \\
\text { Health is the best wealth, Health } \\
\text { is more expensive than gold, } \\
\text { Health is more expensive than } \\
\text { money, One cannot buy health. } \\
\text { The ethno-specific features are: } \\
\text { «normal condition of the } \\
\text { organism», «social health», } \\
\text { «strong, solid built», «nimble, } \\
\text { artful». }\end{array}$ & $\begin{array}{l}\text { A physiological-psychological human } \\
\text { condition is accepted the most } \\
\text { important aspect in his or her life. } \\
\text { Health is understood as integrity of } \\
\text { the organism, sustainability of its } \\
\text { functioning. Healthy mind in a healthy } \\
\text { body. He who has health has hope, } \\
\text { and he who has hope has everything. } \\
\text { Health is better than wealth. The } \\
\text { ethno-specific features are: "degree } \\
\text { of success", "happiness", "the work of } \\
\text { providing medical services". }\end{array}$ & $\begin{array}{l}\text { In the Chinese culture a relationship } \\
\text { between the material wealth and health } \\
\text { is emphasized. Wealth as a means of } \\
\text { providing a normal life influences the } \\
\text { human physical and mental health. A } \\
\text { long life or a nearly death - this } \\
\text { depends upon wealth. Run out of } \\
\text { money, and the human dies. On the } \\
\text { other hand, wealth brings physical and } \\
\text { mental fatigue to people. Wealth tires } \\
\text { out the human. Satiety damages the } \\
\text { stomach. }\end{array}$ \\
\hline $\begin{array}{l}\text { Health as a sense } \\
\text { of moderation }\end{array}$ & $\begin{array}{l}\text { The Russian proverbial stock } \\
\text { inculcates a necessity to }\end{array}$ & $\begin{array}{l}\text { In the English language the } \\
\text { importance of moderation for one's }\end{array}$ & $\begin{array}{l}\text { Alonglifeis the most important good for } \\
\text { the Chinese, so they treat their health }\end{array}$ \\
\hline
\end{tabular}




\begin{tabular}{|l|l|l|l|}
\hline & $\begin{array}{l}\text { observe such habits as } \\
\text { neatness, cold training, moving } \\
\text { activity, refusal to bad habits, } \\
\text { moderation in food and drinks. } \\
\text { Moderation is the mother of } \\
\text { health. Move more - will live } \\
\text { longer. Lie after lunch, walk after } \\
\text { dinner. }\end{array}$ & $\begin{array}{l}\text { health is also emphasized. Besides, } \\
\text { the connection between good mood } \\
\text { and health is pointed out. } \\
\text { Temperance is the best physic. To } \\
\text { lengthen thy (=your) life, lessen thy } \\
\text { (=your) meals. Health and } \\
\text { cheerfulness mutually beget each } \\
\text { other. }\end{array}$ & $\begin{array}{l}\text { carefully. The proverbs about } \\
\text { moderation are fixed in the language. } \\
\text { Moderation in meals is better than a } \\
\text { hundred doctors. If you eat a little less } \\
\text { for dinner, than you will live up to 99 } \\
\text { years. Do not smoke, nor drink alcohol, } \\
\text { and disease will go around you. }\end{array}$ \\
\hline $\begin{array}{l}\text { Health as a good, } \\
\text { gift from above }\end{array}$ & $\begin{array}{l}\text { Health is a basis for happiness, } \\
\text { gives an opportunity to live and } \\
\text { work completely. Health is a gift } \\
\text { from God, which may transfer } \\
\text { into a harm. Then, from the } \\
\text { viewpoint of the Russian } \\
\text { Orthodox religion, God gives a } \\
\text { disease to the human for } \\
\text { correction («to show patience, to } \\
\text { clean from passions»). }\end{array}$ & $\begin{array}{l}\text { notions, as well as with medical } \\
\text { institutions, in addition, with natural } \\
\text { resources as a means of diseases } \\
\text { prevention. Perhaps, that is the } \\
\text { reason why the word «wellness» } \\
\text { acquired its place in the modern } \\
\text { language, which is used to designate } \\
\text { the condition of physical and spiritual } \\
\text { prosperity. }\end{array}$ & $\begin{array}{l}\text { In the Chinese language the physical } \\
\text { and spiritual constituents of health are } \\
\text { considered separately. Only when } \\
\text { physically healthy, one may work } \\
\text { much, and advanced industry } \\
\text { describes the Chinese national } \\
\text { character. There are unique physical } \\
\text { exercises for improving one's physical } \\
\text { strength (Wushu). Emotions make a } \\
\text { considerable impact on physical health } \\
\text { of a person. When one feeling goes } \\
\text { beyond the controlled borders, it will } \\
\text { harm a corresponding internal organ. }\end{array}$ \\
\hline
\end{tabular}

\section{Conclusions}

The inter-linguistic comparisons, performed in the given research, have enabled to distinguish the national and international components in the content of the concept of «health» in various languages. In particular, we have found out that etymologically the word «здоровье» (health) has fixed in the Russian language in its older meaning «strong as a tree», whereas the etymology of the word «health» in the Roman and Germanic branches is connected with the IndoEuropean structure *kai-lo-, *kai-lu-, having the features «whole», «unharmed».

The contextual analysis has shown that within the last hundred years the word «robuste» applied to health, with the origin from the Latin rōbustus - "oak, strong, healthy», went out of use from the Roman languages. So, this parallel between the etymology of the word «health» in the Slavic and Roman languages is lost at present.

The lexicographical analysis of the concepts of «health» has enabled to distinguish considerable similarities between the Russian and English languages with some differences. The comparison of the given languages with Chinese demonstrates serious differences in linguistic world images of the Europeans and the Chinese. In particular, in all three compared languages health is considered as an absolute value, but in Russian health is the most important value, which is placed higher the material goods; in English health is understood as integrity of the organism; in Chinese wealth is a means of providing physical and mental health. In the British linguoculture health is mostly associated with medical terms, including the medical institutions. In Russian a view towards health as a gift from God and a basis of happiness is preserved. In the Chinese culture health is considered in the interrelation with an opportunity to work much physically.

Summing up the performed linguoculturological analysis of the concept of «health», it can be concluded that there is some similarity of features of the given concept in various cultures. Nevertheless, the ethnonational specific features can also be distinguished, caused by the mentality of the people, macroeconomic, landscape-natural, and other connotations of health experience.

\section{References}

Amiyants O.J. (2008). Translation Equivalents of Phraseological Units with a Key Component «Health» in the English and German Languages. [Online] Available: http://pglu.ru/upload/iblock/491/uch_2009_iii_00040.pdf (last accessed October 17, 2015).

Belozerova A.V. \& Loktionova N.M. (2013). Linguoculturology as a Linguistic Discipline. Philological sciences, 1. [Online] Available: http://www.science-education.ru/107-7681 (last accessed October 14, 2015).

Derbisheva Z.K. (2003). National Mentality and its Reflection in the Language. Monumentaaltaica. [Online] Available: http://altaica.ru/ Articles/mentalitet.htm (last accessed October 10, 2015).

Gachev G.D. (2007). National World Views: Kosmo-Psikho-Logos. Moscow: Academic project.

Jiang Sh. (2015). Concept health in the Russian and Chinese Proverbs: Master's Degree Dissertation. [Online]. Available: http://hdl.handle.net/10995/31709 (last accessed October 15, 2015).

Kirilenko E.I. (2005). Concept of Health in the Russian Language Tradition. Bulletin of Siberian Medicine, 3, pp. 66-74.

Kobeleva G.Y. (2007). Concepts of HEALTH and DISEASE as Fragments of the Russian Language World View. [Online] Available: 
http://conf.msu.ru/archive/Lomonosov_2007/19/kobeleva_gu.doc.pdf (last accessed October 12, 2015).

Kolesov V.V. (1986). Human World in the Word of the Ancient Rus. Leningrad: Leningrad University Publishing House.

Kozyr P.B. (2007). Problem of Health Value in the Historical Aspect. Bulletin of Tomsk State University, 301, pp. 20-22.

Makarov N.P. (2004). Complete Russian-French Dictionary. Prepared according to Edition: Petrograd, 1916 (13 ${ }^{\text {th }}$ edition). Moscow: Astrel.

Maslova V. (2001). Linguoculturology. Moscow: Academia.

Mayorova O.A. (2012). Cognitive Resource of a Word in the Human Health Aspect. BashkortostanMedicalBulletin, 1, Vol. 7, pp. 134137.

Milic O.V. (2014). The Interpretation of the Concept «health» in Seneca. Scientific-practical journal «Philology and Literature Studies». [Online] Available: http://philology.snauka.ru/2014/05/813 (last accessed October 10, 2015).

Pak I.Y. (2006). Linguoculturology as Consequence of Sciences Integration Process. Principles of Linguoculturological Analysis. Scientific Mission of MEPhl-2006, Volume 16, pp. 183-185.

Petkau A.Y. (2013). Olfactory Image of the Concept health in the Russian Language Consciousness. Ural Philological Bulletin, 4, pp. 101-109.

The World Atlas of Languages. (1998). Comrie B. (author), Matthews S., \& Polinsky M. (editors): translated by T. Parfenova. SaintPetersburg: Lik press.

Tulenkova A.V. (2008). Concepts of «Health» and «Disease» in the English and Russian Linguocultures: author's abstract of thesis. [Online] Available: http://www.dslib.net/sravnit-jazykoved/koncepty-zdorove-i-bolezn-v-anglijskoj-i-russkoj-lingvokulturah.html (last accessed September 24, 2015).

Usacheva A.N. (2005). Anthology of Concepts. In V.I. Karasik \& I.A. Sternin (Eds.), Health (pp. 110-118). Volgograd, Paradigma.

Vasmer M. (1973). Etymological Dictionary of the Russian Language. [Online] Available: http://fasmerbook.com/ (last accessed September 22, 2015).

Zenyukova A.A. (2015). Ethnic Special Features of the Concept of «health» in the Russian and British World Views. [Online] Available: http://www.sgu.ru/sites/default/files/textdocsfiles/2015/02/26/zenyukava_a._a._etnospecifika_koncepta_zdorove_v_russkoy_i_brit anskoy_kartinah_mira_pdf (last accessed October 13, 2015). 